\title{
ЦЕРИЙ В КОМПОНЕНТАХ ЛАНДШАФТА ШЕРЛОВОГОРСКОГО ГОРНОРУДНОГО РАЙОНА (ЮГО-ВОСТОЧНОЕ ЗАБАЙКАЛЬЕ)
}

\author{
Юргенсон Георгий Александрович1, \\ yurgga@mail.ru
}

\author{
Солодухина Мария Анатольевна', \\ mabn@ya.ru
}

Филенко Роман Андреевич1, filrom@yandex.ru
1 Институт природных ресурсов, экологии и криологии СО РАН, Россия, 672002, г. Чита, а/я 1032, ул. Недорезова, 16а.

\begin{abstract}
Актуальность исследования заключается в необходимости познания биогеохимии лантаноидов в природно-антропогенном ландшасрте.

Целью работы является изучение поведение церия в геосистеме уникального редкометалльно-олово-полиметаллического Шерловогорского горнопромышленного района в Юго-Восточном Забайкалье.

Методология исследования заключается в изучении поведения церия в звеньях иепи: горная порода (руда) $\rightarrow$ почва (технозем) $\rightarrow$ растение $\rightarrow$ корневая система $\rightarrow$ наземная часть. Отбор проб почвообразующих горных пород, руд, почв и растений проведен в течение полевых сезонов 2001-2016 г2. Пробы почв отобраны в соответствии с ГОСТ 17.4.4. 02-84, по искусственным обнажениям. В работе использованы данные анализа 37 проб горных пород и руд, 211 почв, 119 техноземов и 215 проб (3225 экземпляров) травянистых растений.

Методика работы заключалась в минералого-геохимическом изучении горных пород и руд с использованием оптической и электронной микроскопии. Химический состав горных пород, минералов, почв, техноземов и растений изучен методами ICP MS.

Результаты. Впервые изучено поведение церия в ландшафрте Шерловогрского рудного поля. Основным источником церия в почвах и технозамах рудного района является монацит-(Сe). Он находится в грейзенах и квариево-жильных телах, локализованных в Шерловогорском гранитном массиве, окисленных рудах, хранящихся на складах некондиционных руд и отвалах. Другими носителями церия являются агардит и гоудейит. Он входит также в состав флюорита (8,2-1182 ррт), вольфрамита (0,4-11,1ppm), глин остаточных полостей в жилах, продуктивных на камнесамоцветное сырье (3,3-206 ррт). Незначительны содержания церия в берилле (0,1-1,2 ppm) и топазе (0,2-2,81 ppm). Содержание Се в сульфидном минеральном комплексе в жилах с камнесамоцветным сырьем варьирует от 5,6 до 99,4 ppm. В мелкообломочном материале почв и техноземов содержание Се находится в пределах 0,0051-0,0384 \%. В экспериментах показана возможность выноса церия на ландшасрт водными растворами, содержащими до 0,73 ppm. На всех участках среднее содержание в почвах находится в пределах 3,3-310 ppm, а в техноземах - 30-377 ppm. Максимальное содержание иерия (ppm) установлено в корнях травянистых растений $(1,0-3,9)$ (КБП 0,02-0,03), а минимальное - в их наземных частях (0,8-1,4) (КБП 0,01-0,02). Это свидетельствует о весьма незначительном захвате его растениями и низком содержании в кормовой части пастбищных растений. Однако насколько это безопасно для домашних животных, пока не известно и требует специальных исследований.
\end{abstract}

\section{Ключевые слова:}

Церий, ландшафот, почва, технозем, растение, коэффрициент биологического поглощения, накопление, органы растения, Шерловогорский горнорудный район, Забайкалье.

\section{Введение}

Существенным негативным фактором состояния окружающей среды являются отходы горного производства, в которых минералы-носители токсичных элементов находятся в измельченном состоянии, обладают значительно большей поверхностью и становятся объектом агрессивной деятельности воды, воздуха, углекислоты, микроорганизмов [1]. Особенно это относится к отвальным хвостам обогатительных фабрик. Интерес к содержанию лантаноидов вообще и церия в частности достаточно стабилен и особенности его появления в почвах в результате выветривания гранитоидов даны в [2-4]. По данным А.А. Ганзеева [5] из минералов щелочно-гранитных магматических систем, в частности кукульбейского интрузивного комплекса, к которому относятся граниты Шерловогорского массива, концентраторами легких редкоземельных элементов (РЗЭ) являются TR- пирохлор, бастнезит, монацит, эшинит, чевкинит, развитых в Забайкалье. Концентрации и условия подвижности РЗЭ в почвах обсуждаются в мировой литературе: установлено, что содержания РЗЭ в почвах зависят от свойств почвообразующей породы, степени ее выветрелости, содержания глинистых минералов, органического вещества и других факторов и варьируют в пределах 0,2-86,4 ppm для почвы [5-11]. По данным В.В. Иванова, среднее содержание церия в почвах составляет $43 \pm 14$ ppm [5]. Содержание церия в глинах рыхлого материала полостей из жил, продуктивных на камнесамоцветное сырье Шерловой Горы, находится в пределах 20-200 ppm [12]. Вариации содержания церия в техноземах хвостохранилищ ряда остановленных рудников составляют (ppm) 0,5-17,8 для золотополиметаллических руд, 7,9-72,9для золото-молибденовых. В ряде работ рассмотрена геохимия церия в водной среде [8-10, 13-16]. При 
этом перенос водными потоками происходит преимущественно во взвесях [16]. Показано, что в озерных осадках могут формироваться фторкарбонаты Р3Э [17]. Установлено, что относительная подвижность церия (удельная гидратация $\mathrm{DH}^{0}$ ) $\mathrm{Ce}^{3+}$ достаточно высокая, так же как лантана и иттрия, и варьирует от 1 до 11 ккал/г [5]. Для $\mathrm{Ce}^{4+}$ она уменьшается от 11 до 27,5 [5]. О вероятных формах миграции РЗЭ имеются данные В.А. Чудаевой и О.В. Чудаева, свидетельствующие о содержании растворенного церия в кислых водах рек на 2-3 порядка выше, чем в щелочных [16].

Особенностью РЗЭ является их совместное нахождение в земной коре, и суммарное содержание $\mathrm{La}, \mathrm{Ce}$ и $\mathrm{Nd}$ составляет около $10^{-3} \%$ [5; 17-19]. Церий среди лантаноидов относится к самым распространенным, и его кларк земной коры равен 70 ppm [5; 17-19]. Токсичность стабильных изотопов Се слабо изучена. Потенциал ионизации 20,08 кДж/моль. В земной коре, в отличие от лантана и других лантаноидов, проявляет валентность $3^{+}$и $4^{+}$. Химически активен и легко гидратируется, $\mathrm{Ce}(\mathrm{OH})_{3}$ легко переходит в раствор. Основными минералами-носителями РЗЭ являются: монацит, ксенотим, фторкарбонаты, а также тантало-ниобаты. Среди монацитов преобладают их цериевые разности. Непосредственно в самих гранитоидах также преобладают РЗЭ цериевой подгруппы, тогда как в рудных минералах пегматитов и грейзенов относительно широко развиты менее распространенные тяжелые РЗЭ иттриевой подгруппы. Например, в вольфрамитах грейзенов Шерловой Горы резко преобладают тяжелые РЗЭ, что связано с накоплением их в остаточных расплавах $[20,21]$ и обусловлено, вероятно, лантаноидным сжатием, определяющим накопление в них тяжелых РЗЭ [22].

В условиях гипергенеза проявляется способность церия, как и всех лантаноидов, к комплексообразованию и, вероятно, выносу и миграции их при участии грунтовых вод и атмосферных осадков на ландшафте с образованием пока еще не выявленных элементорганических соединений и твердых минеральных фаз. Во всяком случае, первый опыт изучения минеральных форм редкоземельных элементов в зоне окисления, Шерловогорского месторождения, развивающейся в дезинтегрированном, в том числе глыбовом материале, образовавшемся в открытых горных выработках, показал их достаточно ощутимое развитие [23]. Согласно [6], РЗЭ могут мигрировать из верхних кислых горизонтов почв в более глубокие и сорбироваться гидроксидами железа и марганца. Известно также обогащение РЗЭ глинистой фракции почв [3], на что однозначно указывают также и наши данные [12].

На примере почв Западного Забайкалья выявлено, что концентрации легких РЗЭ возрастают по мере увеличения в профиле почвы содержания глинистых частиц, лессовых отложений, карбонатов, что может приводить к формированию комплексных карбонатных соединений, сорбции РЗЭ подстилающими по- кровными суглинками $[6,24]$. В серой лесной почве валовое содержание церия и его подвижных форм значительно варьировало по профилю [6, 24]: в верхнем горизонте валовое содержание элемента составляло 39,3 ppm и с глубиной возрастало до 62,3 ppm (горизонт Вк), а затем в нижнем слое почвы (57-75 см) происходило уменьшение валового содержания Се до 54,9 ppm. По данным авторов $[6,24]$ легкие РЗЭ отличаются низкой миграционной способностью в щелочной среде, что подтверждено в результате изучения форм миграции церия и лантана в реках [16].

Тем не менее имеющиеся в литературе данные о поведении церия не дают основания проследить его поведение в компонентах ландшафта горнопромышленного района. В этом отношении весьма важным является изучение поведения химических элементов в системе горная порода (руда) $\rightarrow$ кора выветривания (зона окисления) $\rightarrow$ почва (технозем) $\rightarrow$ биота в определенном хорошо изученном горнопромышленном районе. Данные о РЗЭ в почвах и растениях имеются в незначительном числе работ [11, 25-27]. Установлена зависимость сверхкларковых содержаний токсикогенов в природных почвах и техноземах от рудноформационной принадлежности разрабатываемых рудных месторождений. Выявлены типохимические особенности геотехногенных ландшафтов и отходов горного производства в них от геохимической специализации рудных месторождений и вмещающих их околорудных горных пород [1]. Тем не менее было показано, что прямой зависимости содержания этих элементов в растениях от содержания их в почвах нет. Способность растений усваивать эти элементы обусловлена долей их растворимых, прежде всего, водорастворимых форм. Поэтому коэффициенты поглощения их растениями обычно невелики [6].

Одним из наиболее изученных в смысле ландшафтно-геохимических исследований является Шерловогорский горнопромышленный район в Восточном Забайкалье. Здесь на протяжении почти 300 лет с перерывами производилась и производится добыча полезных ископаемых [28]. Однако, несмотря на относительно широкое развитие в его пределах редкометалльной минерализации и присутствие в грейзенах и жилах, содержащих монацит, редкоземельные арсенаты $[24,28,29]$ и другие минералы, изучение РЗЭ и наиболее распространенного из них церия (соотношение содержаний $\mathrm{Ce} / \mathrm{La}$ равно примерно 2) в ландшафте не производилось.

Распределение и поведение РЗЭ в почвах и растениях изучено крайне недостаточно [30, 31]. Поэтому целью исследования является выявление источников Се и его содержания в почвах, техноземах и травянистых растениях степного природно-техногенного ландшафта Шерловогорского горнопромышленного района.

\section{Объект, материалы и методы исследования}

Шерловогорский горнопромышленный район (рис. 1) находится на Юго-востоке Забайкалья, в Борзинском районе Забайкальского края. 


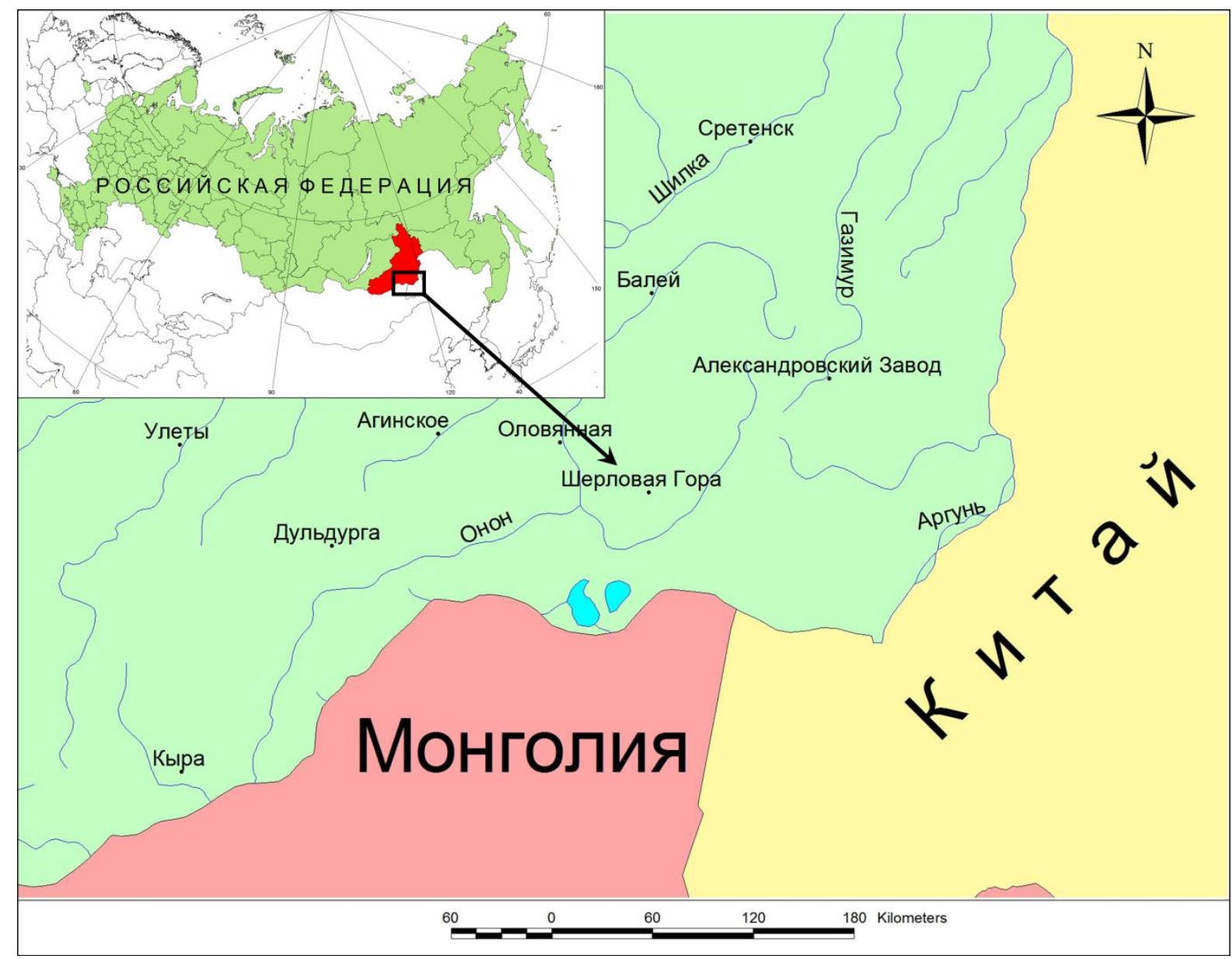

Pис. 1. Местоположение Шерловогорского горнопромышленного района

Fig. 1. Location of Sherlovogorsk mining region

Шерловогорский горнопромышленный район включает пять месторождений, представленных на геологической карте (рис. 2), сформировавшихся вследствие функционирования одноименной рудномагматической системы в юрско-меловое время [28]. Абсолютный возраст её охватывает интервал 153-136 млн лет тому назад.

Основными структурными элементами рудного поля являются Шерловогорский гранитный массив кукульбейского магматического комплекса, с которым связано образование редкометалльно-олововольфрамово-висмутового оруденения с самоцветами месторождения Шерловая Гора, и тела субвулканических кислых образований, с которыми связано оловополиметаллическое оруденение месторождений Сопка Большая и Восточная аномалия $[23,28]$. Общая, генеральная, стадийность формирования месторождений заключается в том, что во времени грейзеновая стадия, с которой связано редкометалльно-олововольфрамово-висмутовое оруденение с самоцветами, сменяется типично гидротермальным оловополиметаллическим [23]. Продукты последнего в виде сульфидно-касситеритовой ассоциации (касситерит, арсенопирит, сфалерит, пирит, галенит, сульфосоли мышьяка и сурьмы) накладываются на минеральные ассоциации грейзеновых жил. Они широко распространены в пределах рудного поля. Важнейшей особенностью всего рудного поля является геохимическая специализация с высокими содержаниями таких токсичных химических элементов, как мышьяк, сурьма, висмут, свинец, цинк, кадмий, вольфрам и молибден $[1,28,29]$. В связи с тем, что на месторождении интенсивно развита зона окисления, источниками указанных элементов в почвах являются их сульфатные и другие анионогенные формы, отличающиеся достаточной подвижностью $[24,28]$.

Здесь развит типичный природно-техногенный ландшафт, в состав которого входит карьер, хвостохранилище, отвалы бедных и забалансовых руд, а также группа олово-полиметаллических и редкометалльных с камнесамоцветным сырьем месторождений, разрабатывавшихся Шерловогорским ГОКом, деятельность которого прекращена в 1993 г. Техногенные массивы, образовавшиеся вследствие работы комбината, постепенно начали зарастать пионерными растениями, такими как полынь Гмелина, таран (горец) узколистный, дендрантема Завадского, мак голостебельный и др. [29].

Отбор проб почвообразующих горных пород, руд, почв и растений был проведен в течение полевых сезонов 2001-2016 гг. на территории Шерловогорского рудного района (рис. 3). 


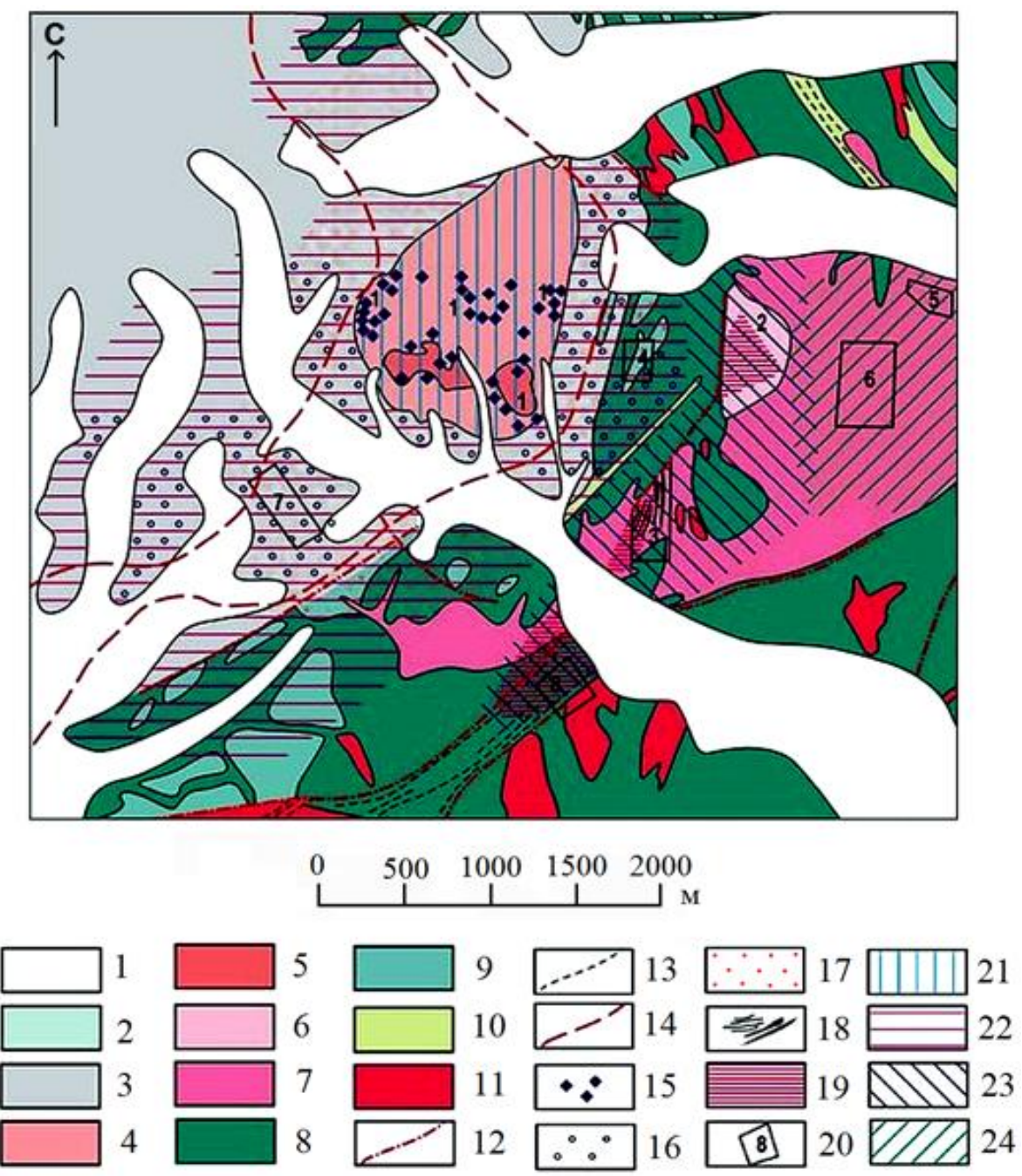

Pис. 2. Схематическая геологическая карта Шерловогорского рудного поля по [28]: 1) четвертичные отложения; 2) отложения нижнего мела, тургинский ярус: песчаники, аргиллиты, конгломераты; 3) нижний карбон: сланцево-песчаниковая толща с прослоями эффузивных пород и реже известняков с фауной турневизейского возраста; 4) гранит-порфир и порфировидный гранит (Mz); 5) равномерно среднезернистый гранит; 6) эруптивная брекчия квариевых порфиров II фазы (Mz); 7) субинтрузивные квариевые порфиры I фазы; 8) диоритовые порфириты и порфириты, реже габбродиорит-порфириты, габбродиориты и диориты (Pz); 9) флюидальные порфириты, их туфы и туфобрекчии (Pz), 10) серпентиниты (по ультрабазитам); 11) плагиограниты и граниты палеозоя; 12) разрывные нарушения; 13) зона смятия, рассланцевания и дробления; 14) предполагаемое подземное продолжение Шерловогорского массива гранитов; 15) грейзеновые тела; 16) участки грейзенизащии во вмещяающи гранить породах; 17) зона контактового метаморфизма; 18) квари-турмалиновые жилы с оловом; 19) зоны турмалинизации; 20) рудные участки и их номера: 1 - Шерловогорский грейзеново-вольфрамовый, 2 - Сопка Большая, 3 - Квари-турмалиновый отрог, 4 - Аплитовый отрог, 5 - Северо-восточный, 6-Восточный, 7 -верховье пади Заводской, 8-Высокий; 21-24 - зоны минерализаичи: 21 - вольфрамитовая-грейзеновая в гранитах; 22 - квари-полевошпат-вольфрамиткасситеритовая; 23 - турмалино-сульфидно-касситеритовая; 24 - сфалерит-галенитовая со слабым сульфиднокасситеритовым оруденением.

Fig. 2. Schematic geological map of Sherlovogorsk ore field by [28]. 1) Quarternary; 2) Lower Cretaceous, Turga Formation sandstone, mudstone and conglomerate; 3) Lower Carboniferous shale and sandstone sequence intercalated with volcanic rocks and less frequent Tournaisian-Vise fossils; 4) Mesozoic porphyry granite and porphyritic granite; 5) equigranular medium-grained granite; 6) Mesozoic eruption breccia of second-phase quartz porphyry; 7) subvolcanic first-phase quartz porphyry; 8) Paleozoic porphyry diorite and porphyries, less frequent porphyry gabbro-diorite, gabbro-diorite, and diorite; 9) Paleozoic flow porphyries, their tuff and tuff breccia; 10) serpentinite after ultramafic rocks; 11) Paleozoic plagiogranite and granite; 12) faults: (a) revealed, (b) presumable; 13) shear zone; 14) presumable underground continuation of the Sherlova Gora granite pluton; 15) greisen bodies; 16) greisenized zones within country rocks; 17) zone of contact metamorphism; 18) Sn-bearing quartz-tourmaline veins; 19) tourmaline zones; 20) ore areas and its numbers: 1 -Sherlova Gora greisen wolframite, 2 - Bolshaya Hill, 3 -Quartz-Tourmaline spur, 4 - Aplite spur, 5 - severo-vostochny, 6 - Vostochny, 7 - Upper Zavodskaya fold, 8 Vysokaya; 21-24) Mineralized zones: 21) greisen wolframite within granite; 22) quartz-feldspar-wolframitecassiterite; 23) tourmaline-sulfide-cassiterite; 24) sphalerite-galena with poor sulfide-cassiterite mineralization 


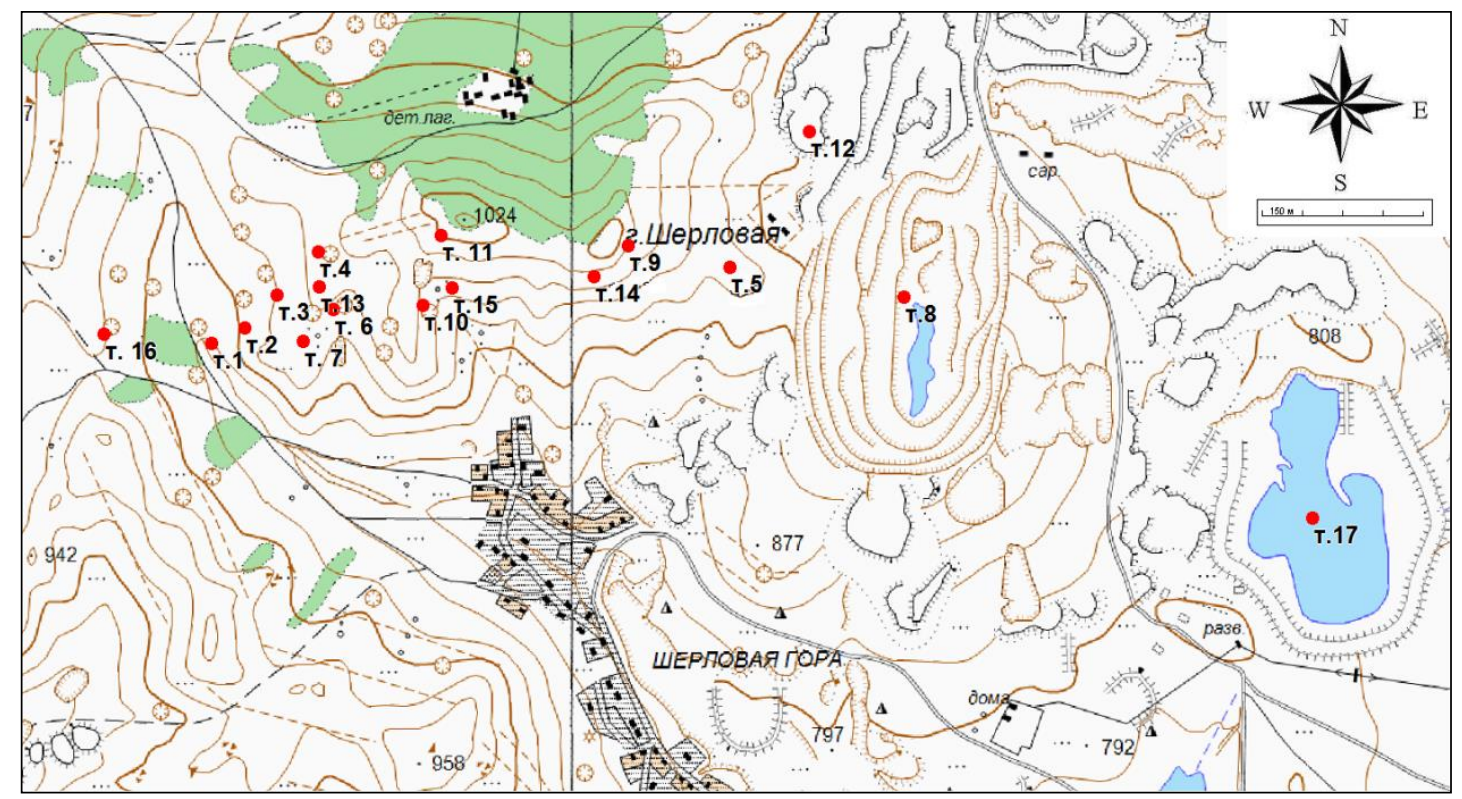

Рис. 3. Картосхема отбора проб. Места отбора проб: Т. 1-T. 4 - точки профиля, Т. 5 - Аплитовый отрог, T. 6 жила Новая, Т. 7 - Карамьлшевский отрог, Т. 8 - карьер, Т. 9 - сопка Лукавая, Т. 10 - сопка Мелехинская, T. 11 - сопка Обвинская, T. 12 - отваль, T. 13 - участок Поднебесных, T. 14 -участок Пятисотка, T. 15 участок Новикова, T. 16- фоновый участок, T. 17 -хвостохоранилище

Fig. 3. Sampling circuit. Sampling sites: T. 1-T. 4 - profile points, T. 5 - Aplitovy spur, T. 6 - Novaya Vein, T. 7 Karamyshevsky spur, T. 8 - open pit, T. 9 - Lukavaya hill, T. 10 -Melekhinskaya hill, T. 11 - Obvinskaya hill, T. 12 dumps, T. 13 - Podnebesnykh site, T. 14 -Pyatisotka site, T. 15 -Novikova site, T. 16-background site, T. 17 - tailing

Пробы почв отобраны в соответствии с ГОСТ 17.4.4.02-84, по искусственным обнажениям. На каждом участке наблюдения проводили по точкам, хорошо изученным в геологическом отношении, где отбирали объединенные пробы доминантных видов растений из каждого яруса, которые встречаются на всех участках. Растения делили на органы. Корни и наиболее запыленные части растений промывали сначала струей проточной воды, а затем дистиллированной, и высушивали до воздушносухого состояния. Каждая проба растений формировалась из 15 экземпляров с площади $10 \times 10$ м. В данной работе использованы результаты анализа 215 проб (3225 экземпляров) травянистых растений (типичная сухостепная растительность). Изучение горных пород, руд, почв и техноземов проводилось стандартными методами. Исследование минерального состава выполнено в иммерсионных препаратах, шлифах и аншлифах на поляризационном микроскопе Axio Scope.A1. Химический состав минералов определен с использованием растрового электронного микроскопа LEO 1430 VP (аналитики Е.А. Хромова, Е.В. Ходырева, ГИН СО РАН, г. Улан-Удэ, руководитель лаборатории к.т.н. С.В. Канакин). Глинистая фракция полостей в продуктивных жилах месторождения Шерловая Гора отмывалась дистиллированной водой, взмучивалась и отстаивалась для сохранения в суспензии лишь глинистых частиц. Химические анализы руд, горных пород и глин выполнены методом ICP MS в лаборатории ОАО «Bосток лимитед», руководители Т.Л. Попова, А. Шацких. Содержание церия в горных породах, рудах, глинах, почвах и техноземах определено методом ICM40B,
НПО 0,1 ppm, в растворах и воде методом IMS84T, НПО - 0,01 ppb. Химический анализ растений произведен методом ICP-MS на спектрофотометре ICP-MS Elan 9000 PerkinElmer (США) методом кислотного разложения ПНД Ф 16.1:2.3:3.11-98, Стандартный образец: Тр-1 (ГСО № 8922-2007), в Хабаровском инновационно-аналитическом центре Института тектоники и геофизики им. Ю.А. Косыгина ДВО РАН, аналитики А.В. Штарева, В.Е. Зазулина, Л.С. Боковенко, А.Ю. Лушникова, Д.В. Авдеев, Е.М. Голубева. Нижний порог определения (НПО) для церия $\sim 0,001$ мкг/кг. Часть анализов почв и техноземов произвели методом РФА (НПО для церия \%) в ГИН СО PAH (г. Улан-Удэ) на спектрометре VRA-30, аналитики к.т.н. Б.Ж. Жалсараев, Ж.Ш. Ринчинова.

Диагностика минералов проводилась методами рентгено-структурного анализа в

Центре коллективного пользования «Геодинамика и геохронология» Института земной коры СО РАН. Образцы, истёртые в яшмовой ступке со спиртом до состояния пудры, исследованы методом порошковой дифракции на дифрактометре ДРОН-3.0, излучение $\mathrm{CuK} \alpha, \mathrm{Ni}$ - фильтр, V=25 кB, I=20 мА, в диапазоне $3-60^{\circ}(2 \theta)$, шаг сканирования $-0,05^{\circ}$. Полученные данные использованы для идентификации фазового состава образцов, используя программу поиска фаз с помощью минералогической базы данных PDF-2 (2007 г.). Для достоверности результатов рентгенофазового анализа дополнительно проведено рентгенфлуоресцентное определение содержаний основных и примесных элементов на кристалл-дифракционном 
спектрометре S8 Tiger (Bruker Nano GmbH, Германия). Для проведения дифрактометрических исследований глинистой составляющей выделялась тонкая фракция, для чего образцы были истерты резиновым пестиком в дистиллированной воде. Полученная суспензия нанесена на предметные стекла и высушена при комнатной температуре. Проводилось по 3 съемки для каждого образца: воздушно-сухого, насыщенного этиленгликолем и прокаленного до $550{ }^{\circ} \mathrm{C}$. Аналитики 3.Ф. Ущаповская, Т.С. Филева. Термогравиметрический анализ осуществлялся в Институте природных ресурсов, экологии и криологии СО РАН (ИПРЭК СО РАН), в лаборатории геохимии и рудогенеза на приборе Netzsch STA 449F1. Условия выполнения: скорость $10{ }^{\circ} \mathrm{C}$ в мин, нагревание до $1000-1200{ }^{\circ} \mathrm{C}$ в потоке аргона или воздуха. Масса образца составляла 10-20 мг, использовался платиновый или корундовый тигель.

\section{Результаты и их обсуждение}

Изучен минеральный состав грейзенизированных гранитов, вмещающих продуктивные на $\mathrm{Be}, \mathrm{W}, \mathrm{Bi}, \mathrm{Sn}$ и камнесамоцветное сырье кварцево-жильные тела, материал полостей в них, содержащиеся в них ассоциации глинистых минералов, минералы-носители церия, почвы и техноземы, травянистые растения. Наибольший вклад в содержание Се в почвах вносят обломки грейзенизировнных гранитов, грейзенов, рудных ассоциаций, содержащих 51-384 ppm Ce. Основным источником церия является монацит, присутствующий в грейзенах и кварцево-жильных телах, локализованных в Шерловогорском гранитном массиве, окисленных рудах, хранящихся на складах некондиционных руд и отвалах, в почвах, а также цериевые агардит и гоудейит. Наиболее важным из них является монацит-(Се).

Монацит-(Ce) (Ce, $\mathrm{La} \mathrm{PO}_{4}$ установлен на Шерловой Горе Е.И. Доломановой (1963), которая указывает на его широкую распространенность в качестве акцессорного минерала в гранитах и в рудных телах с камнесамоцветным сырьем. Обычно размеры кристаллов монацита варьируют от долей миллиметра до 5 мм. В рудных телах он находится преимущественно в прожилках кварцево-топазового, мусковит-флюоритового состава, также в кварцевых и плагиоклазовых агрегатах. Присутствует монацит и в сидерофиллитовых грейзенах. Относительно крупные его кристаллы находятся в кварцево-турмалиновой породе, во флюорит-биотитовых жилках, а также в крупнокристаллических кварцевовольфрамитово-берилловых агрегатах продуктивных тел, залегающих в шерловогорских гранитах. Асcоциирует он с апатитом, биотитом, флюоритом, топазом, турмалином, молибденитом, вольфрамитом (рис. 4).

Наиболее крупные (до 4,1 см) темно-желтые до красновато-бурых толстотаблитчатые кристаллы монацита обнаружены нами в ассоциации с ферберитом, дымчатым кварцем, бериллом и сидерофиллитом в 2008 г. в одной из новых выработок Панкратова на южном склоне Сопки Лукавой на переходе к Золотому отрогу (рис. 4). Он присутствует также в турма- лин-арсенопирит-топазово-кварцевой жиле, разрабатывавшейся М. Свинарёвым и А. Панкратовым в карьере Докучаева на переходе к жиле Новиковской. Результаты электронно-зондового анализа (рис. 5) такой ассоциации приведены в табл. 1. Из неё видно, что кристаллы его от 50 до 100 микрон находятся в кварце $(1,2)$ и скородите, развившемся по арсенопириту в результате окисления последнего. С монацитом ассоциирует бесториевый циркон простого состава $(\%, \mathrm{Zr} 51,68 ;$ Si 33,25; O 15,07). Весь торий в этой системе захвачен монацитом.

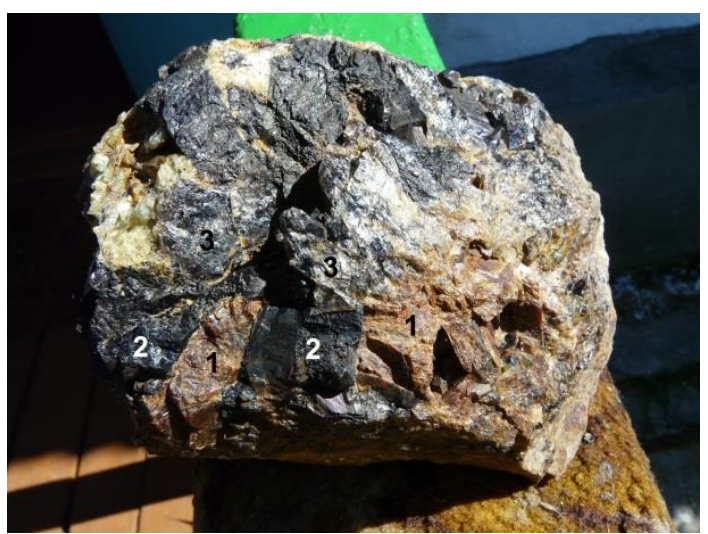

Pис. 4. Кристалль монацита (1) в ассоџиачии с ферберитом (2) и дымчатым кварием (3) $(7 \times 6)$ см. Обр. ШГ-08-474. Шерловая Гора. Выработка Панкратова. Фото О.К. Смирновой

Fig. 4. Monazite crystals (1) in association with ferberite (2) and smoky quartz (3) $(7 \times 6) \mathrm{cm}$. Sample ShG-08-474. Sherlovaya Gora. Pankratov mining. Photo by O.K. Smirnova

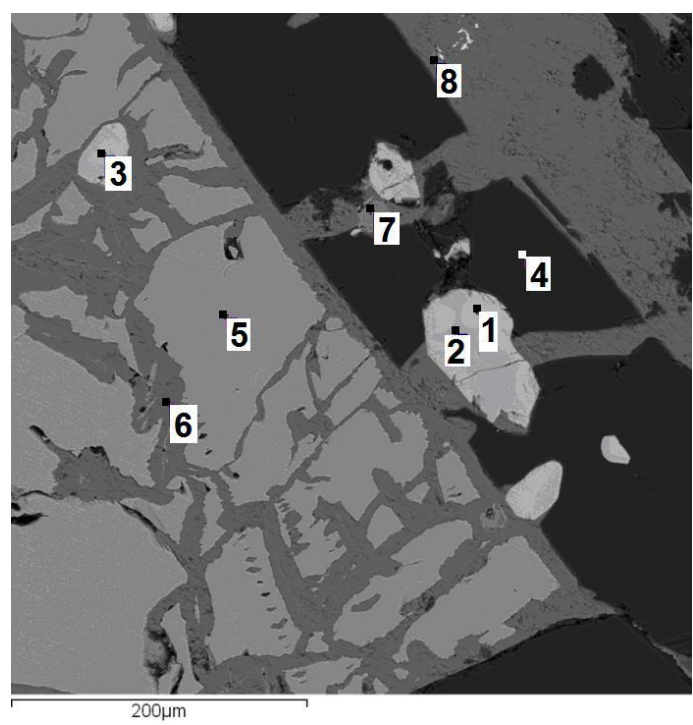

Puc. 5. Монацит (1, 2, 3) в ассочииации с кварием (4), арсенопиритом (5), скородитом (6), цирконом (7), плюмборузвельтитом (8). Электронномикроскопический снимок. Обр. ШГ-16/202. Шерловая Гора. Карьер Докучаева

Fig. 5. Monazite (1, 2, 3) in association with quartz (4), arsenopyrite (5), scorodite (6), zircon (7), plumborooseveltite (8). Image BSE. Sample ShG-16/202. Sherlovaya Gora. Dokuchaev quarry 
Известия Томского политехнического университета. Инжиниринг георесурсов. 2020. Т. 331. № 3. 159-173

Юргенсон Г.А., Солодухина М.А., Филенко Р.А. Церий в компонентах ландшафта Шерловогорского горнорудного района ...

Таблица 1. Химический состав монацита (Се), приведенный к $100 \%$

Table 1. Monazite (Ce) chemical composition, reduced to $100 \%$

\begin{tabular}{|c|c|c|c|c|c|c|c|c|c|c|c|}
\hline \multirow{2}{*}{$\begin{array}{l}\text { Образец } \\
\text { Sample }\end{array}$} & \multicolumn{10}{|c|}{$\begin{array}{c}\text { Элемент и его содержание, мас. \% } \\
\text { Element and its content, wt. \% }\end{array}$} & \multirow{2}{*}{$\begin{array}{l}\text { Сумма } \\
\text { Total }\end{array}$} \\
\hline & $\mathrm{Ca}$ & $\mathrm{Ce}$ & $\mathrm{La}$ & $\mathrm{Pr}$ & $\mathrm{Nd}$ & $\mathrm{Sm}$ & $\mathrm{Gd}$ & Th & $\mathrm{P}$ & $\mathrm{O}$ & \\
\hline $16 / 202-1$ & 0,49 & 26,98 & 10,98 & 3,08 & 11,09 & 1,84 & H.o. & 8,21 & 12,44 & 24,88 & 100,00 \\
\hline $16 / 202-2$ & H.o. & 29,58 & 10,78 & 3,87 & 11,46 & 2,73 & 2,29 & 1,49 & 13,51 & 24,3 & 100,00 \\
\hline $16 / 202-3$ & H.o. & 27,73 & 11,75 & 2,94 & 9,22 & 1,59 & 2,11 & 6,94 & 12,8 & 24,91 & 100,00 \\
\hline $13 / 187-8$ & H.o. & 30,45 & 13,09 & 2,79 & 11,01 & 1,47 & H.o. & 5,82 & 12,77 & 21,18 & 100,00 \\
\hline
\end{tabular}

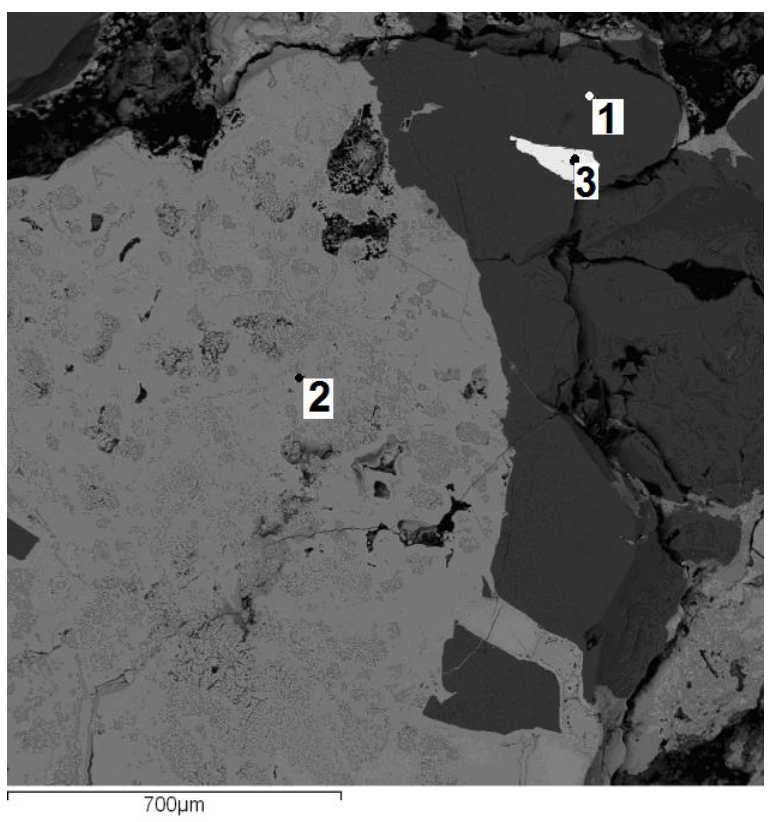

Puc. 6. Монаиит в квари-гетитовой ассочиаиии: 1 квари, содержащий 0,29\% Al; 2 - гётит, содержаший 0,38\% As; 3 - монацит $\left(\mathrm{Ce}_{2} \mathrm{O}_{3} 33,09\right.$; $\mathrm{La}_{2} \mathrm{O}_{3}$ 15,22; $\mathrm{Pr}_{2} \mathrm{O}_{3} 3,03 ; \mathrm{Nd}_{2} \mathrm{O}_{3} 11,93 ; \mathrm{Sm}_{2} \mathrm{O}_{3}$ 1,58; $\mathrm{ThO}_{2}$ 6,14; $\mathrm{P}_{2} \mathrm{O}_{5}$ 27,15). Обр. ШШГ-13/187-8, Шерловая Гора, Сопка Мелехинская

Fig. 6. Monazite in the quartz-goethite association: 1 quartz containing 0,29\% Al; 2 - goethite containing $0,38 \%$ As; 3 - monazite $\left(\mathrm{Ce}_{2} \mathrm{O}_{3} 33,09 ; \mathrm{La}_{2} \mathrm{O}_{3}\right.$ 15,22; $\mathrm{Pr}_{2} \mathrm{O}_{3}$ 3,03; $\mathrm{Nd}_{2} \mathrm{O}_{3}$ 11,93; $\mathrm{Sm}_{2} \mathrm{O}_{3}$ 1,58; $\mathrm{ThO}_{2}$ 6,14; $\mathrm{P}_{2} \mathrm{O}_{5}$ 27,15). Sample ShG-13/187-8, Sherlovaya Gora, Melekhinskaya hill

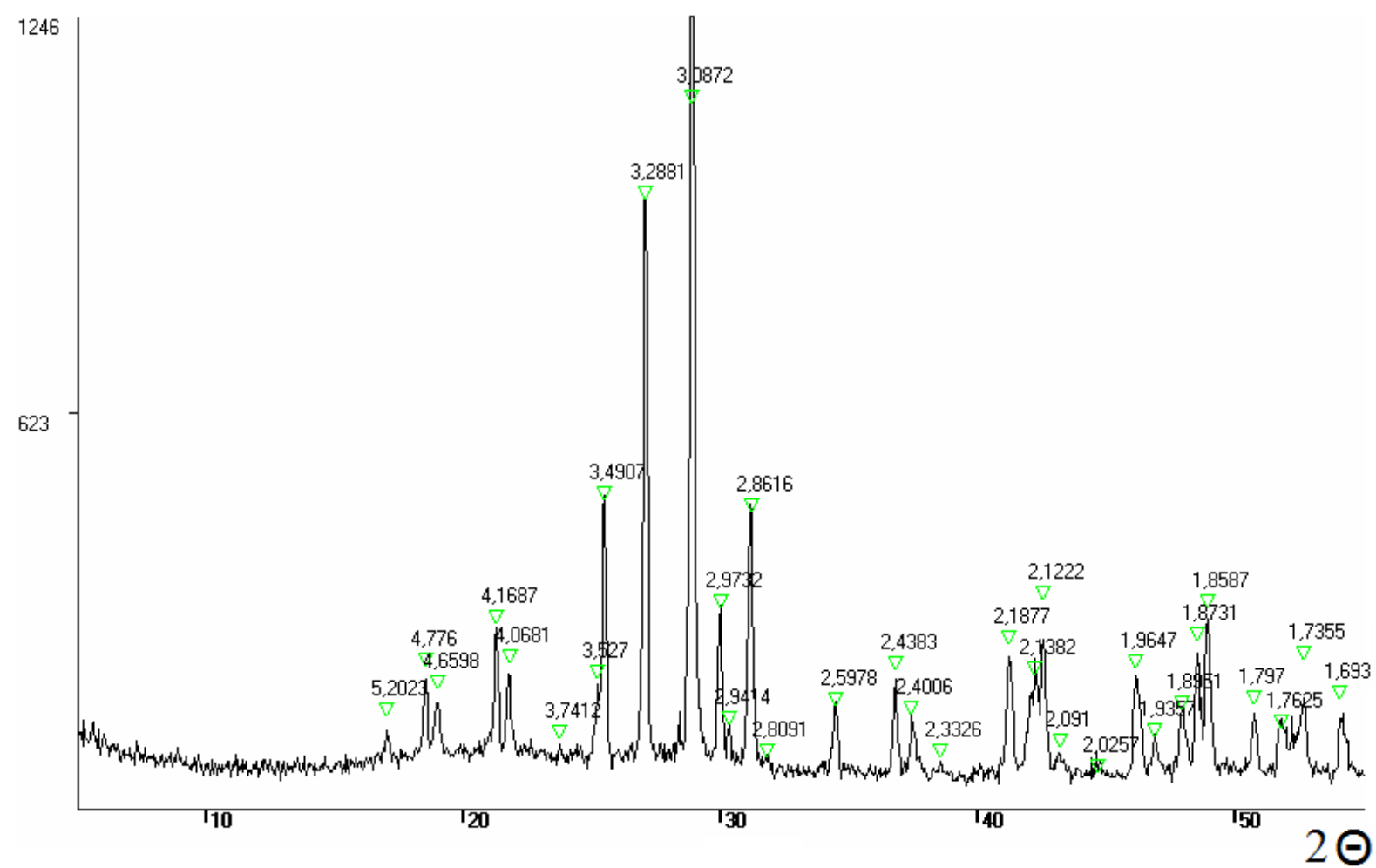

Рис. 7. Дифрактограмма монацита в ассоциации с ферберитом и кварием. Параметры моноклинной элементарной ячейки монацита-(Се) из образиа ШГ-08-474 (̊̊): $a=6,78(1), b=6,98(1), c=6,45(1) \AA, \beta=103,62(8)^{\circ}, V=297(1) A^{3}$

Fig. 7. Monazite diffractogram in association with ferberite and quartz. The parameters of the monoclinic unit cell monazite-(Ce) from sample ShG-08-474 (A): $a=6,78(1), b=6,98(1), c=6,45$ (1) $\AA, \beta=103,62(8)^{\circ}, V=297$ (1) $\AA^{3}$ 
Особенностью изученного монацита является почти равное с лантаном содержание неодима и резкое (почти в три раза) преобладание церия над лантаном. Обычно их содержания примерно равны (\%): $\mathrm{Ce}_{2} \mathrm{O}_{3}-$ $34,99, \mathrm{La}_{2} \mathrm{O}_{3}-34,74$ с небольшим преобладанием церия. При этом безгадолиниевый монацит содержит максимальное количество тория.

Дифрактограмма монацита из образца ШГ-08-474 (рис. 7), где он находится в ассоциации с ферберитом и кварцем (участок Лукаво-Золотая, выработка Панкратова) (табл. 2), также свидетельствует о принадлежности монацита к цериевой разновидности.

Агардит и гоудейит известны в окисленных рудах Шерловогорского месторождения и впервые детально описаны А.В. Касаткиным, К.И. Клопотовым и Я. Плашилом [24]. Агардит развит в СевероВосточном и Южном отвалах окисленных руд в виде сплошных тонких корочек «...бирюзового цвета площадью до нескольких см²» [24. С. 101]. Встречаются также сферолиты и сростки мелких игольчатых кристалликов минерала различных оттенков зеленого цвета: голубовато-зеленых, бледно-зеленых, травянозеленых до бирюзового. Длина кристаллов не превышает 0,6 мм при толщине 1-5 мкм. Блеск стеклянный, иногда шелковистый. Они прозрачны, сгруппированы в тонковолокнистые агрегаты. Церий, по данным [24. С. 101], определен лишь в пяти образцах из 21 проанализированных в количестве $0,13-1,38 \%$. Параметры гексагональной элементарной ячейки со-

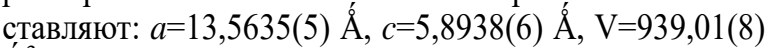
$\AA^{3}$. В гоудейите этими авторами установлен церий в трех образцах из девяти проанализированных в количестве $0,36-0,73 \%$.

Глины в полостях квариево-жильных тел. Церий достаточно распространен в рыхлом материале в пределах рудного поля (до 0,3 \%). Широко распространенными носителями церия являются глины, входя-

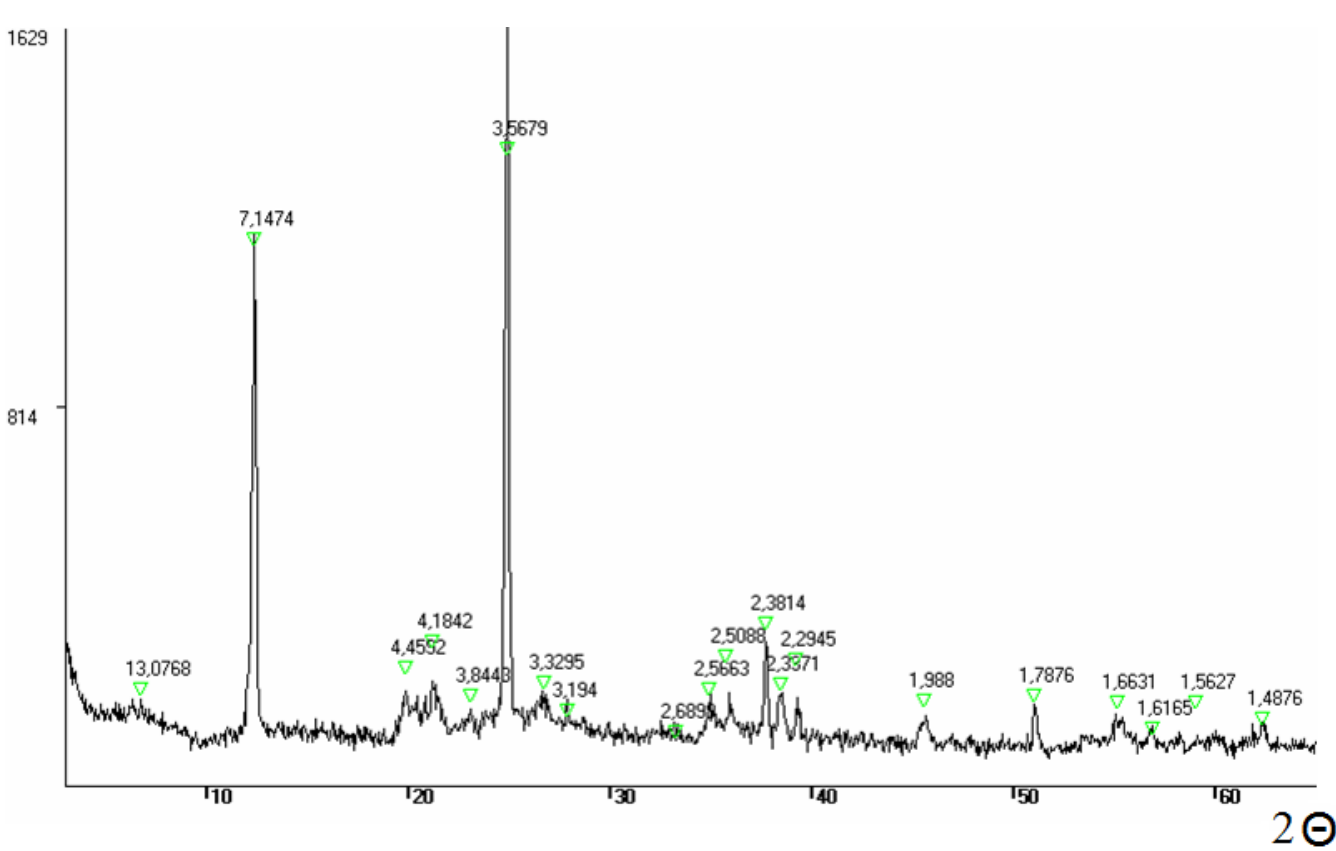

Рис. 8. Дифрактограмма каолинита со следами квариа и полевого шпата

Fig. 8. Diffraction pattern of kaolinite with traces of quartz and feldspar щие в состав рыхлых отложений в полостях жильных тел, продуктивных на вольфрам, висмут, олово и бериллий и содержащих ювелирные разности берилла, топаза и кварца. Окраска глин варьирует от почти белых каолинитовых до бурых с высоким содержанием железа - смектитовых. Глина цементирует фрагменты кристаллов кварца, топаза, берилла, вольфрамита, флюорита или их сростков с сульфидами и поздними карбонатами как в песчаной, так и более крупных фракциях. Среди глин выявлены каолинитовые (образец ШГ-12/209, рис. 8), смектитовые, смешано-слойные (рис. 9).

Рентгенофазовым анализом установлены: кварц, смектит, смешано-слойный смектит-хлорит и каолинит. Примесь кварца и берилла не искажает содержаний в нем церия. Эта ассоциация содержит (ppm) $\mathrm{Ce}$ $(28,7), \mathrm{La}(31,9), \mathrm{Lu}(0,83), \mathrm{Tb}(1,68), \mathrm{Y}(80), \mathrm{Yb}(5,5)$, $\mathrm{Zr}(49,9), \mathrm{Hf}(2,56), \mathrm{U}(15,4), \mathrm{Th}(4,9)$.

Содержание церия в отмученных пробах глин варьирует от 0,05 до $310 \mathrm{ppm}$, составляя в среднем 72,2 ppm. Флюорит содержит 6,32-117,8 ppm Се, вольфрамит 0,88-4,17 ppm. Существенно меньший вклад в содержания церия в почвах вносят тончайшие обломки сульфидов (халькопирит, пирит, галенит, сфалерит и др.), входящие в состав олово-полиметаллических руд. Присутствуют среди них и мельчайшие обломки грейзенов и грейзенизированных гранитов, горных пород среднего состава (диориты и их вулканические аналоги). В результате экспериментов определено, что церий вымывается из глин водой с $\mathrm{pH}=6,9-7,2$. Содержание его в промывных растворах широко варьирует в пределах 0,01-256 ppb (0,01-256 мкг/л). Это позволяет полагать вынос его на ландшафт в местах выхода на дневную поверхность вскрытых эрозией жильных тел, содержащих рыхлый материал полостей в них, а также техногенно-делювиальные скопления в местах разработки рудных тел. 


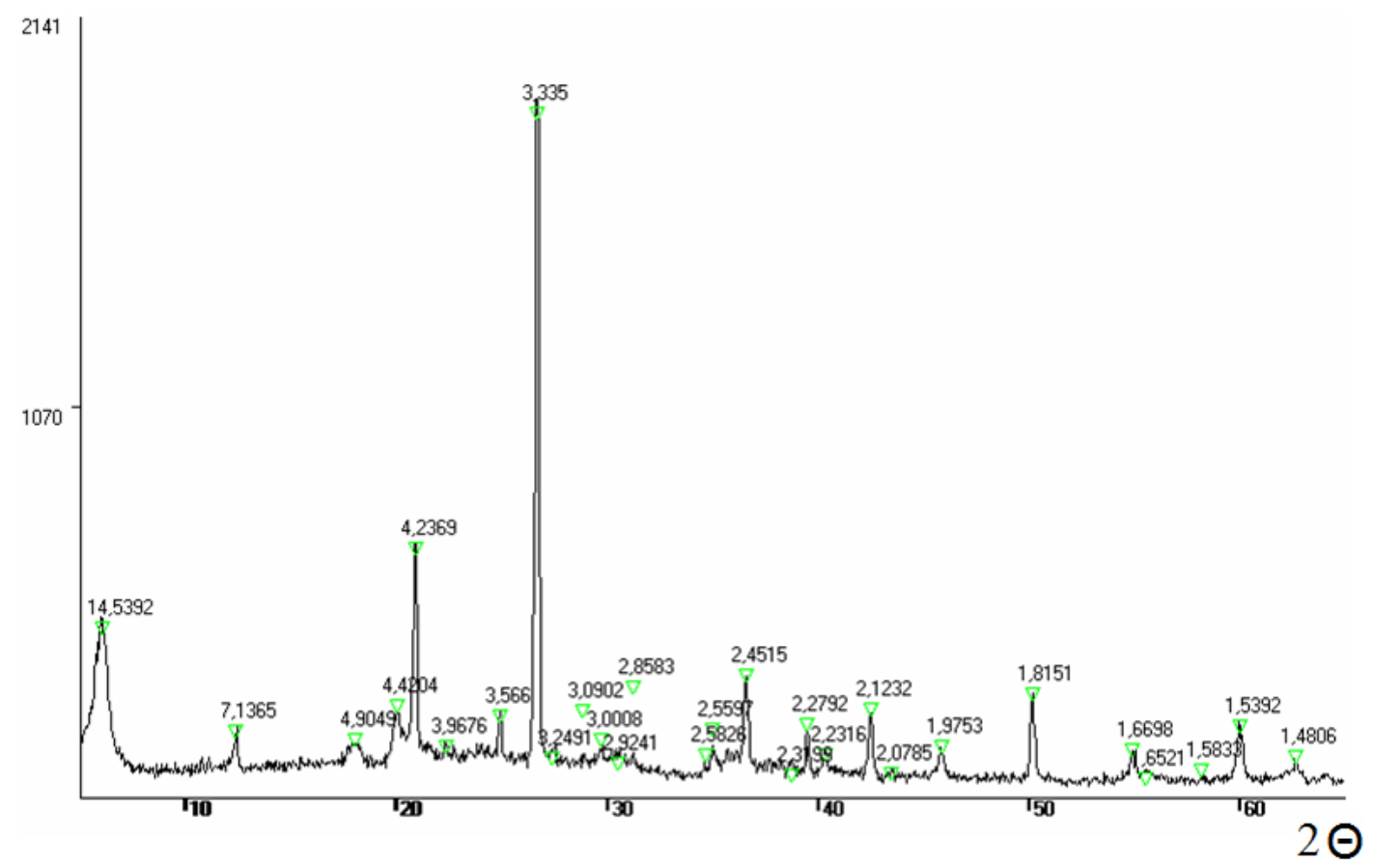

Pис. 9. Дифрактограмма образиа глины сложного состава ШГ-13/186. Состав пробы: квари, смектит, смешанослойный смектит-хлорит, примесь каолинита (d/n, A: 7,13; 3,57; 2,56; 2,56; 1,583; 1,481), берилл (d/n, A: 3,97; 3,25; 2,86). Содержит 8,9 ppm Ce

Fig. 9. Diffraction pattern of sample complex composition SHG-13/186. The composition of the sample: quartz, smectite, mixed-layer smectite-chlorite, an admixture of kaolinite $(d / n, A$ : $7.13 ; 3.57 ; 2.56 ; 2.56 ; 1.583 ; 1.481) ;$ beryl $(d / n, A$ : 3.97; 3.25; 2.86). Contains 8.9 ppm Ce

Таблица 2. Статистические характеристики содержания Се в почвообразующих горных породах, почвах и техноземе, ppm

Table 2. Statistical characteristics of Ce content in soil-forming rocks, soils and technosoils, ppm

\begin{tabular}{|c|c|c|c|c|}
\hline \multirow{2}{*}{$\begin{array}{l}\text { Статистические характеристики } \\
\text { Statistical characteristics }\end{array}$} & \multicolumn{2}{|c|}{$\begin{array}{l}\text { Шерловая Гора } \\
\text { Sherlovaya Gora }\end{array}$} & \multirow{2}{*}{$\begin{array}{c}\text { Техногенные массивы } \\
\text { Technogene dumps } \\
\text { Texнозем } \\
\text { Technosoil } \\
\end{array}$} & \multirow{2}{*}{$\begin{array}{c}\begin{array}{c}\text { Фоновый участок } \\
\text { Background area }\end{array} \\
\text { Почва } \\
\text { Soil } \\
\end{array}$} \\
\hline & $\begin{array}{c}\text { Почвообразующие } \\
\text { горные породы } \\
\text { Soil-forming rocks }\end{array}$ & $\begin{array}{c}\text { Почва } \\
\text { Soil }\end{array}$ & & \\
\hline $\begin{array}{l}\text { Cреднее } \\
\text { Average }\end{array}$ & 171,5 & 110,2 & 47,7 & 67,4 \\
\hline \begin{tabular}{|l|} 
Медиана \\
Median \\
\end{tabular} & 110,0 & 104,0 & 63 & 63 \\
\hline $\begin{array}{l}\text { Стандартное отклонение } \\
\text { Standard deviation }\end{array}$ & 110,9 & 48,4 & 15,9 & 25,5 \\
\hline $\begin{array}{l}\text { Минимум } \\
\text { Minimum } \\
\end{array}$ & 30,0 & 21,0 & 8 & 40,0 \\
\hline $\begin{array}{l}\text { Максимум } \\
\text { Maximum } \\
\end{array}$ & 520,0 & 390,0 & 79,0 & 162 \\
\hline $\begin{array}{l}\text { Число проб } \\
\text { Number of samples }\end{array}$ & 37 & 211 & 119 & 17 \\
\hline $\begin{array}{l}\text { Коэффициенты концентрации для средних } \\
\text { Concentration factors for medium }\end{array}$ & 2,45 & 1,57 & 0,68 & 0,96 \\
\hline
\end{tabular}

Церий в почвах и техноземах. Среднее содержание Се в почвах составляет 109,4 ppm, при максимальном содержании в почвообразующих горных породах 520 ppm и среднем 171,5 (табл. 2). Статистические характеристики содержания церия в почвообразующих горных породах, развитых на них почвах Шерловогорского рудного района, приведены в табл. 2 .

Коэффициент концентрации церия для средних значений почвообразующих горных пород составляет 2,45 , почв $-1,57$, для техноземов - 0,68 , а для фона почти совпадает с кларком земной коры. Уменьшение содержания церия в техноземах по сравнению с почвообразующими горными породами почти в 4 раза (табл. 2) обусловлено извлечением монацита в тяжелую фракцию при гравитационном способе обогащения касситеритовых руд. Тем не менее максимальные значения концентраций церия для всех изученных косных компонентов ландшафта за исключением технозема кратно превышают кларк. Установлено, что максимальные концентрации церия присущи территории развития Шерловогорского гранитного массива с наложенной грейзеновой минерализацией, соответствующей участкам Сопка Мелехинская, Сопка Обвинская, Сопка Лукавая и 
зона Поднебесных. Содержания, близкие к кларковым, менее типичны для олово-полиметаллического месторождения Сопка Большая и полиметаллического Восточная аномалия, геотехногенного ландшафта и фонового участка на западном фланге рудно-магматической системы (рис. 10). Численные значения содержаний церия в почвах ррm приведены на рис. 11.
Четко прослеживается приуроченность максимальных содержаний церия к участкам развития грейзеновой минерализации с развитием минеральных ассоциаций, содержащих монацит-(Cе) и продуктивных на висмут-бериллий-вольфрамовое оруденение с камнесамоцветным сырьем. Это участки (с запада на восток): Поднебесных, Жила Новая, Сопка Обвинская, участки Новикова и Пятисотка, Сопка Лукавая (рис. 11).

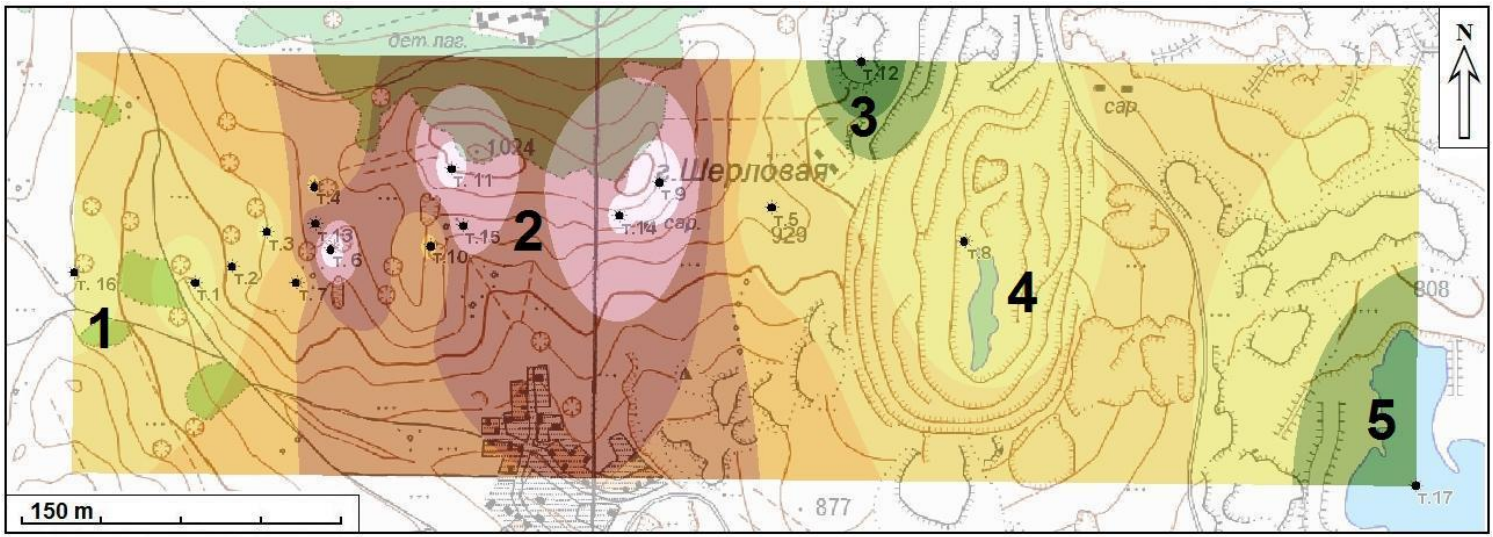

\section{Содержание, ppm}

\begin{tabular}{|c|c|c|}
\hline $35-47$ & 71 - 82 & $106-117$ \\
\hline $48-58$ & $83-93$ & $118-128$ \\
\hline $59-70$ & $94-105$ & $129-1$ \\
\hline
\end{tabular}

Рис. 10. Симметричная зональность распределения конщентраций иерия в ландмафте относительно участков опробования: 1 - за пределами Шерловогорского гранитного массива; 2 - в пределах Шерловогорского гранитного массива с телами грейзенов; 3 - отваль вскрышных пород месторождения; 4 - карьер оловополиметаллического месторождения, 5 - хвостохранилище и склады упорных руд

Fig. 10. Symmetric zonality of cerium concentration distribution in the landscape relative to sampling sites: 1 -outside the Sherlovogorsk granite massif; 2 - within the Sherlovogorsk granite massif with greisen bodies; 3 - dumps of overburden rocks of the deposit; 4 - pit of a tin-polymetallic deposit; 5 -tailing dump and warehouses of resistant ores

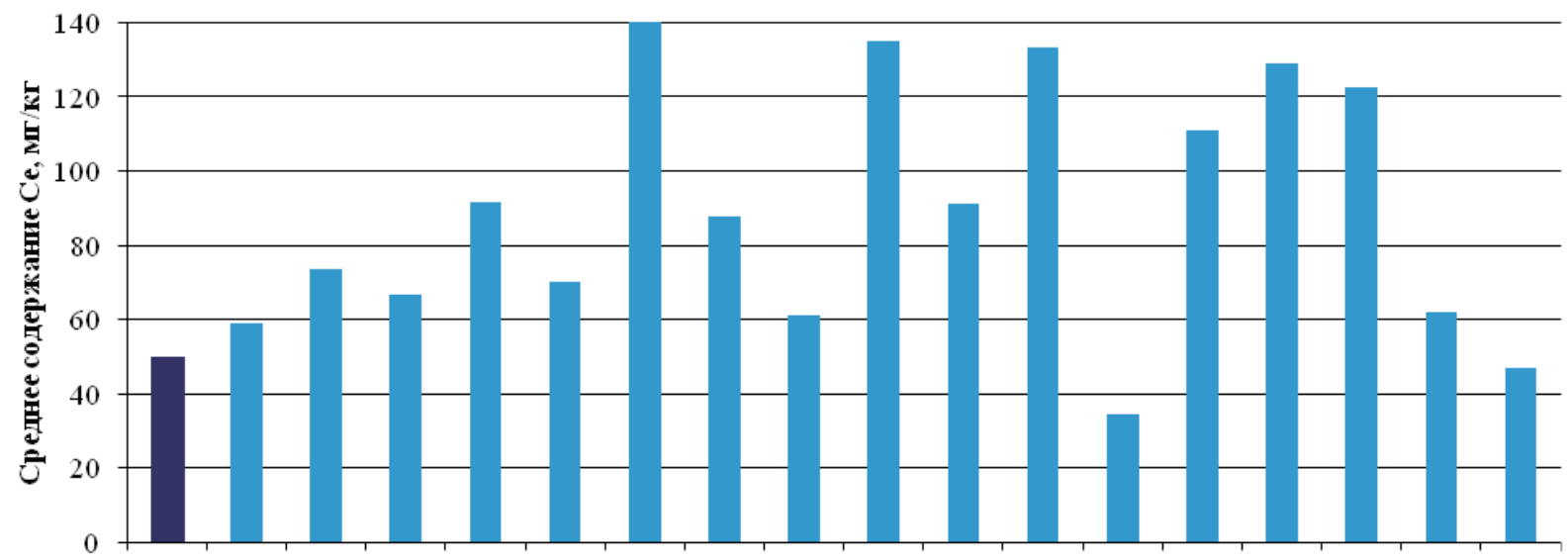

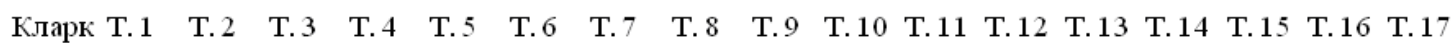

Pис. 11. Среднее содержание Се в почвах на разных участках Шерловогоского рудного района в сравнении с кларком земной коры: Т. 1-Т. 4 - точки профиля, Т. 5 - Аплитовый отрог, Т. 6 - Жила Новая, Т. 7 - Карамышевский отрог, Т. 8 - карьер, Т. 9 - Сопка Лукавая, T. 10 - Сопка Мелехинская, T. 11 - Сопка Обвинская, T. 12 отвалы, Т. 13 - участок Поднебесных, T. 14 - участок Пятисотка, T. 15 - участок Новикова, Т. 16 - фоновый участок, T. 17 -хвостохранилище

Fig. 11. Average content of Ce in soils in different areas of the Sherlovogosk ore area in comparison with the clarke of the earth's crust: T. 1-T. 4 - profile points, T. 5 -Aplitovy spur, T. 6 - Novaya Vein, T. 7 - Karamyshevsky spur, T. 8 open pit, T. 9 - Lukavaya hill, T. 10 - Melekhinskaya hill, T. 11 - Obvinskaya hill, T. 12 -dumps, T. $13-$ Podnebesnykh site, T. 14 - Pyatisotka site, T. 15 - Novikov section, T. 16-background section, T. 17 - tailing dump 
Содержание иерия в растениях. Изучено распределение церия в корневой системе и надземных частях наиболее распространенных пионерных растений, заселяющих природно-техногенный ландшафт Шерловогорского рудного района. К ним относятся: полынь Гмелина, подмаренник настоящий, лапчатка скученная, таран (горец) узколистный, дендрантема
Завадского, мак голостебельный, Иван-чай узколистный и другие. Анализ усредненных аналитических данных по содержанию церия в них показал, что на всех типах ландшафтов Шерловогорского рудного района, включая фоновый участок, содержание его больше в корнях, чем в надземной части растений (табл. 3).

Таблица 3. Содержание Се в травянистых растениях Шерловогорского рудного района

Table 3. Ce content in herbaceous plants of the Sherlovogorsk ore district

\begin{tabular}{|c|c|c|c|c|c|}
\hline \multirow[b]{2}{*}{$\begin{array}{l}\text { Участок отбора проб } \\
\text { Sampling site }\end{array}$} & \multicolumn{4}{|c|}{$\begin{array}{c}\text { Содержание Се в травянистых растениях } \\
\text { Ce content in herbaceous plants }\end{array}$} & \multirow{2}{*}{$\begin{array}{l}\text { Соотношение содержа- } \\
\text { ний в корнях и надзем- } \\
\text { ных частях } \\
\text { Ratio of contents in roots } \\
\text { and aerial parts } \\
\end{array}$} \\
\hline & $\begin{array}{c}\text { Надземная часть } \\
\text { Elevated part } \\
\text { (ppm) }\end{array}$ & $\begin{array}{l}\text { Корни } \\
\text { Roots } \\
(\mathrm{ppm}) \\
\end{array}$ & $\begin{array}{c}\text { КБП надземными } \\
\text { частями } \\
\text { BAC aboveground parts }\end{array}$ & $\begin{array}{c}\text { КБП } \\
\text { корнями } \\
\text { BAC roots }\end{array}$ & \\
\hline $\begin{array}{l}\text { Месторождение Шерловая Гора } \\
\text { Sherlovaya Gora deposit }\end{array}$ & $1,4(97)$ & $3,9(29)$ & 0,01 & 0,03 & 2,8 \\
\hline $\begin{array}{l}\text { Техногенные массивы } \\
\text { Man-made arrays }\end{array}$ & $1,0(57)$ & $1,2(11)$ & 0,02 & 0,03 & 1,2 \\
\hline $\begin{array}{l}\text { Фоновый участок } \\
\text { Background Plot }\end{array}$ & $0,8(16)$ & $1,0(5)$ & 0,01 & 0,02 & 1,25 \\
\hline
\end{tabular}

Примечание: в скобках дано число проб в выборке; КБП - коэффициент биологического поглощения.

Note: the number of samples in the selection given in brackets; BAC-biological absorption coefficient

Максимальное различие в содержаниях церия в растениях характерно непосредственно для участка с висмут-бериллий-вольфрамовым оруденением и камнесамоцветным сырьем Шерловая Гора, где соотношение содержаний церия в корневой системе в 2,8 раз больше, чем в надземной части растений. На фоновом участке эта величина составляет 1,25 , а на геотехногенных массивах она минимальна, составляет 1,2. Преобладание содержаний церия в корневых системах растений может свидетельствовать об их барьерности по отношению к нему. Но для окончательного решения этого вопроса требуется провести исследования распределения церия конкретных видов растений по их органам (корень, стебель, литья, плоды, семена). Опыт изучения распределения химических элементов, в частности мышьяка [29], в растениях показал, что наибольшими концентрациями его характеризуются корни и листья, а наименьшими стебли и семена.

КБП церия корневой системой для участка с максимальным (Шерловая Гора) и минимальным (геотехногенные массивы) его содержанием одинаков. Это указывает на то, что доля усвояемых растениями его форм в техноземах значительно выше, а именно, в $(3,9 / 1,2=3,25)$ раза. Причина различия заключается в существенно большей раскрытости минераловисточников церия в тонкоизмельченном материале техноземов, прошедшем взаимодействие с реагентами обогатительного процесса и находящихся под воздействием атмосфериллий. К ним относятся вода, углекислота, азот и кислород воздуха, создающие кислую среду, в которой церий относительно легко мигрирует, находясь в водорастворимых формах $[12,13,16,17]$.

\section{Выводы}

1. Впервые изучено поведение церия в ландшафте Шерловогрского рудного поля.
2. Основным источником церия в почвах и технозамах рудного района является монацит-(Cе) грейзенов и кварцево-жильных тел, локализованных в Шерловогорском гранитном массиве, окисленных рудах, хранящихся на складах некондиционных руд и отвалах. Другими носителями церия являются: агардит и гоудейит, флюорит, вольфрамит, глины остаточных полостей в жилах, а также в существенной мере берилл и топаз. В мелкообломочном материале почв и техноземов содержание Се находится в пределах 51-384 ppm. В экспериментах показана возможность выноса церия на ландшафт водными растворами, содержащими до $0,73 \mathrm{ppm}$.

3. Содержание церия в почвах находится в пределах 3,3-310 ppm, а в техноземах - 30-377 ppm. Четко прослеживается пространственная симметричная зональность в распространении церия в почвах, обусловленная приуроченностью максимальных содержаний церия к участкам развития грейзеновой минерализации с развитием минеральных ассоциаций, содержащих монацит-(Се), и продуктивных на висмут-бериллий-вольфрамовое оруденение с камнесамоцветным сырьем.

4. Максимальное содержание церия установлено в корнях травянистых растений, а минимальное - в их наземных частях. КБП церия корневой системой для участка с максимальным (Шерловая Гора) и минимальным (геотехногенные массивы) содержанием церия одинаковы. Это обусловлено тем, что доля усвояемых растениями форм его в техноземах в 3,25 раз выше, чем в почвах, развитых на грейзенизированных гранитах и грейзенах с висмут-бериллий-вольфрамовым оруденением.

5. Причина различия заключается в существенно большей раскрытости минералов-источников церия в тонкоизмельченном материале техноземов, прошедших взаимодействие с реагентами обога- 
тительного процесса и находящихся под постоянным воздействием атмосферных вод, углекислоты, азота и кислорода воздуха, создающих кислую среду, в которой церий относительно легко мигрирует, находясь в водорастворимых формах.

6. Важно, что захват церия растениями весьма незначителен и содержание его в кормовой части пастбищных растений составляет всего 0,8-1,4 ppm. Однако насколько это безопасно для домаш-

\section{СПИСОК ЛИТЕРАТУРЫ}

1. Юргенсон Г.А. Типохимизм рудных месторождений как основа для классификации горнопромышленных геосистем и фактор прогноза экологической опасности отходов горного производства // 200 лет РМО: Материалы конференции Юбилейного съезда РМО. - СПб., 2017. - Т. 2. - С. 389-390.

2. Aide M.T., Heberlie L., Statler P. Soil genesis on felsicrocks in the Saint Francois Mountains. II. The distribution of elements and their use in understanding weathering and elemental loss rates during genesis // Soil Science. - 1999. - № 164. - P. 946-959.

3. Behavoir of rare earth elements and other trace and major elements during weathering of granite rocks, Evora, Portugal / M.A. Gouveia, M.I. Prudencio, M.O. Figueiredo, L.C.J. Pereira, J.C. Waerenborgh, I. Morgado, T. Pena, A. Lopes // Chemical Geology. - 1993. - № 107. - P. 293-296.

4. The bahaviour of rare earth elements and $\mathrm{Y}$ during the rock weathering and soil formation in the Ricany granite massif, Central Bohemia / L. Minarik, A. Zigova, J. Bendl, P. Skrivan, M. St'astny // Science of the Total Environment. - 1998. № 215. - P. 101-111.

5. Иванов В.В. Экологическая геохимия элементов. Кн. 6. f-элементы. - М.: Экология, 1997. - 606 с.

6. Кожевникова Н.М. Особенности распределения валового и подвижных форм церия, неодима, самария в профиле серой лесной почвы Забайкалья // Агрохимия. - 2010. - № 6. - С. 65-68.

7. Diatloff E., Asher C.J., Smith F.W. Concentrations of rare earth elements in some Australian soils // Australian journal of soil research. - 1996. - № 34. - P. 735-747.

8. Elderfield H., Upstill-Goddard R., Sholkovitz E.R. The rare earth elements in rivers, estuaries, and coastal seas and their significance to the composition of the ocean waters // Geochimica et Cosmochimica Acta. - 1990. - V. 54. - P. 971-991.

9. Geochemistry of rare earth elements in hypersaline and dilute acidic natural terrestrial waters: complexation behavior and middle rare-earth elements enrichments / K.N. Johannesson, W.B. Lyons, M.A. Yelken, Y.E. Gaudette, K.J. Stetzenbach // Chemical Geology. - 1996. - V. 133. - P. 125-144.

10. Effects of humic acid on speciation and bioavailability to wheat of rare earth elements in soil / Gu Xueyuana, Wang Xiaoronga, Gu Zhimanga, Da Lemeib, Chen Yijun // Chemical Speciation and Bioavailability. - 2001. - № 13 (3). - P. 83-88.

11. Concentration of lanthanide elements, Th and $U$ in 77 Japanese surface soils / S. Yoshida, Y. Muramatsu, K. Tagami, Sh. Uchida // Environment International. - 1998. - V. 24. - № 3. - P. 275-286.

12. Юргенсон Г.А., Яковлева В.Н. Редкоземельные элементы цериевой подгруппы в глинах и промывных водных растворах продуктивных жил Шерловой Горы // Вестник Забайкальского государственного университета. - 2017. - № 12. - С. 51-63.

13. Вах Е.А., Вах А.С., Харитонова Н.А. Содержания редкоземельных элементов в водах зоны гипергенеза сульфидных руд Березитового месторождения (Верхнее Приамурье) // Тихоокеанская геология. - 2013. - Т. 32. - № 1. - С. 105-115.

14. Wood S.A., Shannon W.M., Baker L. The aqueous geochemistry of the rare earth elements and yttrium. Part 13: REE geochemistry of mine drainage from the Pine Creek area, Coeur d'Alene River valley, Idaho, USA // Rare earth elements in groundwater flow systems / Ed. by K.H. Johannesson. - TX, U.S.A.: University of Texas at Arlington, 2005. - P. 89-110.

15. Wolkersdorfer C. Rare earth elements (REEs) as natural tracers in mine waters // Uranium in the Aquatic Environment / Eds. B.J. Merkel, B. Planer-Friedrich, C. Wolkersdorfer. - Berlin, Heidelberg: Springer, 2002. - P. 951-958. них животных, пока неизвестно и требует специальных исследований.

Авторы выражают благодарность коллегам к.г.-м.н. О.К. Смирновой, к.г.-м.н. О.В. Ерёмину, Д.Н. Горбань, принимавшим участие в сборе и подготовке к анализу проб почв и растений.

Работа выполнена согласно госзаданию, проект № 0386-2017-0006.

16. Чудаева В.А., Чудаев О.В. Особенности накопления и фракционирования редкоземельных элементов в поверхностных водах Дальнего Востока в условиях природных и антропогенных аномалий // Геохимия. - 2011. - № 5. - С. 523-549.

17. Борзенко С.В., Замана Л.В., Зарубина О.В. Распределение редкоземельных элементов в водах и донных осадках минеральных озер Восточного Забайкалья (Россия) // Литология и полезные ископаемые. - 2017. - № 4. - С. 306-321.

18. Балашов Ю.А. Геохимия редкоземельных элементов. - М.: Наука, 1976. - 267 с.

19. Виноградов А.П. Средние содержания химических элементов в главных типах изверженных горных пород земной коры // Геохимия. - 1962. - № 7. - С. 555-571.

20. Попова Ю.А., Бычков А.Ю., Матвеева С.С. Геохимические особенности поведения лантаноидов при формировании месторождения Светлое (Чукотка) // Геохимия. - 2016. - № 8. - С. 761-768.

21. Поведение лантаноидов при формировании минерализованных куполов на примере Спокойнинского месторождения (Забайкалье) / Ю.А. Попова, С.С. Матвеева, А.Ю. Бычков, М.Е. Тарнопольская, Я.В. Бычкова // Геохимия. - 2017. - № 2. - С. 178-185.

22. REE in wolframites from Sherlova Gora gems mine (Transbaikalia, Russia) / G.A. Yurgenson, A.Yu. Bychkov, O.V. Kononov, J.A. Popova // Goldschmidt Abstracts. - 2017. - P. 4443.

23. Юргенсон Г.А., Прокофьев В.Ю., Кононов О.В. Физикохимические условия формирования камнесамоцветной и редкометалльной минерализации месторождения Шерловая Гора (Юго-Восточное Забайкалье) // XVIII Всероссийская конференция по термобарогеохимии, посвященная 100-летию со дня рождения профессора Юрия Александровича Долгова, 1918-1993. - М., 24-28 сентября 2018. - М.: Изд-во Первого Московского государственного медицинского университета им. И.М. Сеченова, 2018. - С. 156-158.

24. Kasatkin A.V., Klopotov K.I., Lấšil J. Supergene minerals of Sherlova Gora // Mineralogical Almanac, Mineral-Almanac Limited Lakewood, USA. - 2014. - V. 19. - Iss. 2. - P. 94-139.

25. Содержание тяжелых щелочноземельных ( $\mathrm{Sr}, \mathrm{Ba})$ и редкоземельных (Y, La, Ce) металлов в техногенно-загрязненных почвах / Ю.Н. Водяницкий, А.Т. Савичев, А.А. Васильев, Е.С. Лобанова, А.Н. Чащин, Е.В. Прокопович // Почвоведение. - 2010. - № 7. - С. 879-890.

26. Determination of rare earth elements, thorium and uranium by Inductively coupled plasma mass spectrometry and strontium isotopes by thermal ionization mass spectrometry in soil samples of Bryansk region contaminated due to Chernobyl accident / S.K. Sahoo, H. Yonehara, K. Kurotari, K. Shiraishi, V. Ramzaev, A. Barkovski // The Journal of Radioanalytical and Nuclear Chemistry. - 2004. - V. 247. - № 2. - P. 341-345.

27. Tyler G., Olsson T. Conditions related to solubility of rare and minor elements in forest soils // Journal of Plant Nutrition and Soil Science. - 2002. - № 165. - P. 594-601.

28. Yurgenson G.A., Kononov O.V. Sherlova Gora: a deposit for gemstones and rare metals // Mineralogical Almanac, Mineral-Almanac Limited Lakewood, USA. - 2014. - V. 19. - Iss. 2. - P. 12-93.

29. Солодухина М.А., Юргенсон Г.А. Мышьяк в ландшафтах Шерловогорского рудного района (Восточное Забайкалье). Чита: Изд-во Забайкальского государственного университета, 2018. $-176 \mathrm{c}$.

30. Kabata-Pendias A., Pendias H. Trace elements in soils and plants (2nd ed). - Florida, USA: CRC Press, Boca Raton, 1992. - 365 p.

31. Bowen H.J.M. Environmental chemistry of the elements. London: Adacemic Press, 1979. - 333 p.

Поступила 29.01.2020 2. 
Известия Томского политехнического университета. Инжиниринг георесурсов. 2020. Т. 331. № 3. 159-173

Юргенсон Г.А., Солодухина М.А., Филенко Р.А. Церий в компонентах ландшафта Шерловогорского горнорудного района ...

\section{Информация об авторах}

Юргенсон Г.А., доктор геолого-минералогических наук, главный научный сотрудник лаборатории геохимии и рудогенеза Института природных ресурсов, экологии и криологии СО РАН.

Солодухина М.A., кандидат географических наук, научный сотрудник лаборатории геохимии и рудогенеза Института природных ресурсов, экологии и криологии СО РАН.

Филенко P.A., научный сотрудник лаборатории геохимии и рудогенеза Института природных ресурсов, экологии и криологии СО РАН. 
UDC 550.47

\title{
CERIUM IN THE LANDSCAPE COMPONENTS OF THE SHERLOVOGORSKIY MINING REGION (SOUTHEASTERN TRANSBAIKALIA)
}

\author{
Georgy A. Yurgenson 1 , \\ yurgga@mail.ru
}
Mariya A. Solodukhina ${ }^{1}$, mabn@ya.ru

\author{
Roman A. Filenko', \\ filrom@yandex.ru \\ 1 Institute of Natural Resources, Ecology and Cryology SB RAS, \\ 16 a, Nedorezov street, Chita, 672002, Russia.
}

\begin{abstract}
The relevance of the study is in the need to know the biogeochemistry of lanthanides in natural-anthropogenic landscape.
The aim of the work is to study the behavior of the cerium geosystem of the unique rare-metal-tin-polymetallic Sherlovogorsk mining region in the South-Eastern Transbaikalia.

The research methodology is to study the behavior of cerium in the links of the chain: rock (ore) $\rightarrow$ (technosoil) $\rightarrow$ plant $\rightarrow$ root system $\rightarrow$ ground part. Sampling of soil-forming rocks, ores, soils and plants was carried out during the field seasons 2001-2016. Soil samples were selected in accordance with GOST 17.4.4. 02-84, by artificial outcrops. In this work, the data from analysis of 37 samples of rocks and ores, 211 soils, 119 technozems and 215 samples (3225 specimens) of grassy plants were used.

The method of the work consisted in mineralogical and geochemical study of rocks and ores using optical and electron microscopy. The chemical composition of rocks, minerals, soils, technozems and plants was studied by ICP MS.

Results. The authors have studied cerium behavior in the landscape of the Sherlovogrsk ore field. The main source of cerium in the soils and technosoil of the ore region is monazite-(Ce). It is located in greisens and quartz-vein bodies, localized in the Sherlovogorsk granite massif, oxidized ores stored in substandard depots and dumps. Other carriers of cerium are agardite and godeite. It is also included in the composition of fluorite (8,2-1182 ppm), wolframite $(0,4-11,1 \mathrm{ppm})$, clay residual cavities in the veins, which are productive for gemstone raw materials (3,3-206 ppm). The content of cerium in beryl (0,1-1,2 ppm) and topaz (0,2-2,81 ppm) are insignificant. The content of Ce in the sulfide mineral complex in the veins with gemstone raw material varies from 5,6 to $99,4 \mathrm{ppm}$. In the finely clastic material of soils and technosoils, the Ce content is in the range of 51-384 ppm. The experiments showed the possibility of transporting cerium onto the landscape with aqueous solutions containing up to $0,73 \mathrm{ppm}$. In all areas, the average content in soils is within 3,3-310 ppm, and in technosoils - 30-377 ppm. The maximum content of cerium (ppm) is set in the roots of grassy plants (1,0-3,9) (CBA 0,02-0,03), and the minimum in their terrestrial parts $(0,8-1,4)$ (KBA 0,01-0,02). This indicates a very slight seizure of its plants and a low content of grazing plants in the forage. However, how safe it is for pets has not been yet known and requires special research.
\end{abstract}

\section{Key words:}

Cerium, landscape, soil, tecnosoil, plant, biological absorption coefficient, accumulation, plant organs, Sherlovogorskiy mining region, Transbaikalia.

The authors express the gratitude to the colleagues O.K. Smirnova, Cand. Sc., O.V. Eremin, Cand. Sc., D.N. Gorban, for participation in collection and preparation of soil and plant samples for the analysis.

The work was performed according to the state project assignments (No. 0386-2017-0006).

\section{REFERENCES}

1. Yurgenson G.A. Tipokhimizm rudnykh mestorozhdeniy kak osnova dlya klassifikatsii gornopromyshlennykh geosistem i faktor prognoza ekologicheskoy opasnosti otkhodov gornogo proizvodstva [Typochemism of ore deposits as the basis for the classification of mining geosystems and prediction factor of the environmental hazard of mining waste]. Materialy konferentsii yubileynogo sezda RMO. 200 let RMO [Proc. of the Conference of the Jubilee Congress of the RMS. $200^{\text {th }}$ anniversary of the RMS]. St. Petersburg, 2017. Vol. 2, pp. 389-390.

2. Aide M.T., Heberlie L., Statler P. Soil genesis on felsicrocks in the St. Francois Mountains. II. The distribution of elements and their use in understanding weathering and elemental loss rates during genesis. Soil Science, 1999, no. 164, pp. 946-959.

3. Gouveia M.A., Prudencio M.I., Figueiredo M.O., Pereira L.C.J., Waerenborgh J.C., Morgado I., Pena T., Lopes A. Behavoir of REE and other trace and major elements during weathering of granite rocks, Evora, Portugal. Chemical Geology, 1993, no. 107, pp. 293-296.
4. Minarik L., Zigova A., Bendl J., Skrivan P., St'astny M. The bahaviour of rare earth elements and $\mathrm{Y}$ during the rock weathering and soil formation in the Ricany granite massif, Central Bohemia. Science of the Total Environment, 1998, no. 215, pp. 101-111.

5. Ivanov V.V. Ekologicheskaya geokhimiya elementov. Kniga 6. f-ehlementy [Ecological geochemistry of elements. B. 6. f-elements]. Moscow, Ecologiya Publ., 1997. 606 p.

6. Kozhevnikova N.M. Distribution of Cerium, Neodymium, and Samarium in Gray Forest Soil of the Transbaikalia. Agricultural Chemistry, 2010, no. 6, pp. 65-68. In Rus.

7. Diatloff E., Asher C.J., Smith F.W. Concentrations of rare earth elements in some Australian soils. Australian journal of soil research, 1996, no. 34, pp. 735-747.

8. Elderfield H., Upstill-Goddard R., Sholkovitz E.R. The rare earth elements in rivers, estuaries, and coastal seas and their significance to the composition of the ocean waters. Geochimica et Cosmochimica Acta, 1990, vol. 54, pp. 971-991.

9. Johannesson K.N., Lyons W.B., Yelken M.A., Gaudette Y.E., Stetzenbach K.J. Geochemistry of rare earth elements in hypersaline and dilute acidic natural terrestrial waters: complexation be- 
havior and middle rare-earth elements enrichments. Chemical Geology, 1996, vol. 133, pp. 125-144.

10. Gu Xueyuana, Wang Xiaoronga, Gu Zhimanga, Da Lemeib, Chen Yijun. Effects of humic acid on speciation and bioavailability to wheat of rare earth elements in soil. Chemical Speciation and Bioavailability, 2001, no. 13 (3), pp. 83-88.

11. Yoshida S., Muramatsu Y., Tagami K., Uchida Sh. Concentration of lanthanide elements, Th and U in 77 Japanese surface soils. Environment International, 1998, vol. 24, no. 3, pp. 275-286.

12. Yurgenson G.A., Yakovleva V.N. Rare earth elements of cerium subgroup in clays and washing aqueous solutions of productive veins of Sherlovaya Gora. Transbaikal State University Journal, 2017, no. 12, pp. 51-63. In Rus.

13. Vakh E.A., Vakh A.S., Kharitonova N.A. The presence of REE in the waters of the hypergenetic zone of the sulfide ores, the Beresitovy deposit (Upper Priamurie). Russian Journal of Pacific Geology, 2013, vol. 32, no. 1, pp. 105-115. In Rus.

14. Wood S.A., Shannon W.M., Baker L. The aqueous geochemistry of the rare earth elements and yttrium. P. 13: REE geochemistry of mine drainage from the Pine Creek area, Coeur d'Alene River valley, Idaho, USA. Rare Earth Elements in Groundwater Flow Systems (edited by Karen H. Johannesson). TX, U.S.A., University of Texas at Arlington, 2005. pp. 89-110.

15. Wolkersdorfer C. Rare earth elements (REEs) as natural tracers in mine waters. Uranium in the Aquatic Environment. Eds. B.J. Merkel, B. Planer-Friedrich, C. Wolkersdorfer. Berlin, Heidelberg, Springer, 2002. pp. 951-958.

16. Chudaeva V.A., Chudaev O.V. Accumulation and fractionation of rare earth elements in surface waters of the Russian Far East under the conditions of natural and anthropogenic anomalies. Geochemistry international, 2011, no. 5, pp. 523-549. In Rus.

17. Borzenko S.V., Zamana L.V., Zarubina O.V. Distribution of rare earth elements in waters and bottom sediments of mineralized lakes in the Eastern Transbaikal region (Russia). Lithology and mineral resource, 2017, vol. 52 (4), pp. 263-277.

18. Balashov Yu.A. Geokhimiya redkozemelnykh elementov [Geochemistry of rare earth elements]. Moscow, Nauka Publ., 1976. $267 \mathrm{p}$.

19. Vinogradov A.P. Srednie soderzhaniya khimicheskikh elementov $\mathrm{v}$ glavnykh tipakh izverzhennykh gornykh porod zemnoy kory [Medium content of chemical elements in the main types of igneous rocks of the earth's crust]. Geokhimiya, 1962, no. 7, pp. 555571.

20. Popova Yu.A., Bychkov A.Yu., Matveeva S.S. Behavior of lanthanides during the formation of the Svetloe deposit, Chukotka. Geochemistry international, 2016, no. 8. pp. 761-768. In Rus.

21. Popova Yu.A., Matveeva S.S., Bychkov A.Yu., Tarnopolskaya M.E., Bychkova Ya.V. Behavior of lanthanides during the origin of mineralized domes: an example of the Spokoininskoe deposit, Transbaikalia. Geochemistry international, 2017, no. 2, pp. 178-185. In Rus.

22. Yurgenson G.A., Bychkov A.Yu., Kononov O.V., Popova J.A. REE in wolframites from Sherlova Gora gems mine (Transbaikalia, Russia). Goldschmidt Abstracts, 2017, pp. 4443.

23. Yurgenson G.A., Prokofev V.Yu., Kononov O.V. Fizikokhimicheskie usloviya formirovaniya kamnesamotsvetnoy i redkometallnoy mineralizatsii mestorozhdeniya Sherlovaya Gora (Yugo-Vostochnoe Zabaykale) [Physico-chemical conditions for formation of stone-precious and rare-metal mineralization of the Sherlovaya Gora deposit (South-Eastern Transbaikalia)]. XVIII Vserossiyskaya konferentsiya po termobarogeokhimii, posvyaschennaya 100-letiyu so dnya rozhdeniya professora Yuriya Aleksandrovicha Dolgova, 1918-1993 [VIII All-Russian Conference on Thermobarogeochemistry, dedicated to the $100^{\text {th }}$ anniversary of the birth of Professor Yuri Alexandrovich Dolgov, 1918-1993]. Moscow, September 24-28, 2018. Moscow, I.M. Sechenov Moscow State Medical University Publ. house, 2018. pp. 156-158.

24. Kasatkin A.V., Klopotov K.I., Plấšil J. Supergene Minerals of Sherlova Gora. Mineralogical Almanac, Mineral-Almanac Limited Lakewood, USA, 2014, vol. 19, Iss. 2, pp. 94-139.

25. Vodyanitskiy Yu.N., Savichev A.T., Vasilev A.A., Lobanova E.S. Chaschin A.N., Prokopovich E.V. Contents of heavy alkaline-earth $(\mathrm{Sr}, \mathrm{Ba})$ and rare-earth $(\mathrm{Y}, \mathrm{La}, \mathrm{Ce})$ metals in technogenically contaminated soils. Eurasian soil science, 2010, no. 7, pp. 879-890. In Rus.

26. Sahoo S.K., Yonehara H., Kurotari K., Shiraishi K., Ramzaev V., Barkovski A. Determination of rare earth elements, thorium and uranium by Inductively coupled plasma mass spectrometry and strontium isotopes by thermal ionization mass spectrometry in soil samples of Bryansk region contaminated due to Chernobyl accident. The Journal of Radioanalytical and Nuclear Chemistry, 2004, vol. 247, no. 2, pp. 341-345.

27. Tyler G., Olsson T. Conditions related to solubility of rare and minor elements in forest soils. Journal of Plant Nutrition and Soil Science, 2002, no. 165. pp. 594-601.

28. Yurgenson G.A., Kononov O.V. Sherlova Gora: a deposit for gemstones and rare metals. Mineralogical Almanac, MineralAlmanac Limited Lakewood, USA, 2014, vol. 19, Iss. 2, pp. 12-93.

29. Solodukhina M.A., Yurgenson G.A. Myshyak $v$ landshaftakh Sherlovogorskogo rudnogo rayona (Vostochnoe Zabaykale) [Arsenic in landscapes of the Sherlovogorsky ore region (Eastern Transbaikalia)]. Chita, Transbaikal Stats University Publ. house, 2018. $176 \mathrm{p}$

30. Kabata-Pendias A., Pendias H. Trace elements in soils and plants $\left(2^{\text {nd }}\right.$ ed.). Florida, USA, CRC Press, Boca Raton, 1992.365 p.

31. Bowen H.J.M. Environmental chemistry of the elements. London, Adacemic Press, 1979. 333 p.

Received: 29 January 2020.

Information about the authors

Georgy A. Yurgenson, Dr. Sc., professor, chief researcher, Institute of Natural Resources, Ecology and Cryology SB RAS.

Mariya A. Solodukhina, Cand. Sci., researcher, Institute of Natural Resources, Ecology and Cryology SB RAS.

Roman A. Filenko, researcher, Institute of Natural Resources, Ecology and Cryology SB RAS. 